\title{
PERWATAKAN MANUSIA BERDASARKAN HARI LAHIR DALAM NASKAH RASPATIKALPA
}

\author{
HUMAN DISPOSITIVE BASED ON BORN DAY \\ IN MANUSCRIPT RASPATIKALPA
}

\author{
Lilis Restinaningsih \\ Undang A. Darsa \\ Titin Nurhayati Ma'mun \\ Konsentrasi Filologi Program Pascasarjana Fakultas Ilmu Budaya Universitas Padjadjaran \\ email: restinalee@gmail.com
}

\begin{abstract}
Abstrak
Raspatikalpa merupakan naskah Merapi-Merbabu yang menjadi koleksi dari PNRI yang tergolong naskah jamak dengan 16 judul naskah yang sama dan satu judul berbeda yaitu Basundarikalpa.Naskah ini berasal dari abad 16-18 dan memiliki sistem aksara dan bahasa yang unik.Raspatikalpa memuat perwatakan manusia berdasarkan saptawara.Penelitian secara filologis harus dilakukan agar naskah Raspatikalpa dapat dibaca oleh masyarakat luas.Prinsip edisi teks naskah Raspatikalpa dilakukan dengan menggunakan prinsip kerja metode landasan (legger).Hasil penelitian menunjukan naskah Raspatikalpa dengan nomer koleksi 131 merupakan naskah dasar edisi teks.secara pragmatik raspatikalpa pada masanya berfungsi sebagai falsafah hidup; bagian dari religiusitas; bagian dari proses inisiasi; dan sebagai jimat.
\end{abstract}

Kata kunci: Raspatikalpa, manuskrip, filologi, saptawara, watak, urip, daur hidup.

\begin{abstract}
Raspatikalpa is the Merapi-Merbabu's manuscript that became a PNRI collection of manuscripts which can only be classified as plural with 16 titles the same script and a different title that comes from Basundarikalpa centuries. The text was made at sixteenth to eighteenth centuries and has a script system and unique language. Raspatikalpa containing the human disposition by Saptawara. The philological research must be done so that the text can be read widely by the public of Raspatikalpa. The principal edition of the manuscript text Raspatikalpa done by use the Working Principle Grounding Method (Legger). The results show that the Raspatikalpa manuscript collection at number 131 is the basic text edition. Pragmatically, Raspatikalpa serves as a philosophy of life in his time; part of religiosity; part of the initiation process; and as a talisman.
\end{abstract}

Keywords: Raspatikalpa, manuscript, philological, saptawara, character, urip, life cycles.

\section{A. PENDAHULUAN}

Manusia adalah makhluk ciptaan Tuhan yang paling sempurna. Mereka dibekali berbagai kemampuan untuk bertahan hidup dan menghadapi berbagai permasalahan. Sejak zaman dulu manusia sudah mulai membuat perhitungan, untuk menerka dan meraba permasalahan yang akan terjadi, dan bagaimana mengatasinya. Kegiatan membuat perhitungan, terkaan atau rabaan disebut juga dengan kegiatan meramal. Aktivitas meramal sudah ada sejak ratusan juta yang lalu dalam berbagai peradaban. 
Sarana ramalan yang paling populer adalah dengan menggunakan ramalan berdasarkan astrologi atau lebih dikenal dengan ramalan bintang. Berdasarkan astrologi, seseorang bisa mengetahui kepribadiannya, pekerjaan yang harus dipilih, kekuatannya, kelemahannya, penyakit yang mungkin akan diderita dan juga kehidupan asmaranya. Perkembangan ilmu astrologi tidak terlepas dari perkembangan ilmu astronomi, namun keduanya memiliki pengertian yang berbeda. Hal ini senada dengan pendapat Lewis dalam bukunya The Astrology Book: The Encyclopedia of Heavenly Influence yang berbunyi:

'Astrology literally means study (or science depending on how one translates the Greeks world logos) of the stars (astron). Astrology differs from astronomy by confining its attention of the study of correlations between celestial events and humanly meaningful events. Most people are familiar with only a tiny portion of science of the stars, namely the 12 signs of the zodiac as they relate to the personality of individuals and the use of astrology for divinatory purposes (2003:xiii)'

"Astrologi adalah ilmu tentang perbintangan. Astrologi berbeda dengan astronomi dengan hanya membatasi perhatiannya untuk mempelajari korelasi benda langit dengan kejadian dalam kehidupan manusia. Kebanyakan orang hanya mengenal sebagian kecil ilmu perbintangan, khususnya 12 tanda zodiak yang dikaitkan dengan kepribadian seseorang dan juga untuk kegiatan meramal."

Masyarakat Nusantara telah mengenal ilmu astronomi sejak zaman purbakala. Hal ini senada dengan pendapat Brandes (1889) bahwa masyarakat Nusantara pada zaman purba telah menggunakan ilmu astronomi sebagai alat bantu pelayaran dan bercocok tanam. Seiring berkembangnya ilmu astronomi, ilmu astrologi pada masyarakat Nusantara juga berkembang, khususnya pada masyarakat Jawa. Ilmu astrologi masyarakat Jawa didasarkan pada sistem penanggalan Jawa yaitu wewaran $^{l}$ (ekawara-dasawara), wuku ${ }^{2}(1$ siklus $=30$ pekan/ 210 hari), dan pranata mangsa ${ }^{3}$.

${ }^{1}$ Wewaran berasal dari bahasa Sanskerta dari
urat kata wara yang diduplikasi (dwipurwa)
dan mendapat akhiran -an (we + wara + an).
Kata wara memiliki arti terpilih; terbaik;
unggul; hari; mulia; dan utama.Dari uraian
tersebut wewaran diartikan sebagai
perhitungan hari-hari.Mitologi lahirnya
wewaran terdapat dalam Lontar Medangkamulan dan Lontar Bagawan Garga (http://dharmavada.wordpress.com/2011/05/25/ pengertian-dan-mitologi-wewara/.Diakses pada 01/09/2014 pukul 19:50).Dalam wewaran dikenal ada sepuluh jenis minggu yang dikenal dalam tradisi Jawa dan Bali.Ekawara merupakan perhitungan hari dengan siklus 1 harian. Dwiwara merupakan perhitungan hari dengan siklus 2 harian.Triwara merupakan perhitungan hari dengan siklus 3 harian.Caturwara merupakan perhitungan hari dengan siklus 4 harian.Pancawara merupakan perhitungan hari dengan siklus 5 harian.Sadwara merupakan perhitungan hari dengan siklus 6 harian. Saptawara merupakan perhitungan hari dengan siklus 7 harian. Hastawara merupakan perhitungan hari dengan siklus 8 harian.Nawawara merupakan perhitungan hari dengan siklus 9 harian. Dasawara merupakan perhitungan hari dengan siklus 10 harian.

${ }^{2} W u k u$ berasal dari pangkal kata wuku yang berarti rahsa, yaitu rasa yang dimiliki oleh tiap-tiap manusia.Dalam pengetahuan orang Jawa rasa dibagi menjadi 3, yaitu rasa luar (rasa jaba), rasa dalam (rasa jero), dan rasa sejati (rasa sejati).Rasa yang terkandung dalam makna wuku adalah rasa dalam yang merupakan manisfestasi hidup manusia.Rasa dalam bekerjasama dengan cipta untuk menggerakkan semua pekerti manusia, yang tiap-tiap manusia, yang bagi tiap-tiap manusia/orang telah mempunyai jatah ukurannya sendiri-sendiri menurut dasar pembawaan yang sudah dimiliki sejak dari waktu kelahirannya.Pawukon berkaitan dengan perjalanan hidup manusia menurut kodrat nasibnya masing-masing menyerupai horoskop dalam astrologi.Pawukon merupakan kebudayaan Jawa asli dalam 1 siklus terdiri 
Wewaran, wuku, pranata mangsa tertuang dalam naskah tulisan tangan di berbagai daerah, mulai dari Jawa, Sunda dan Bali.Salah satu naskah yang memuat mengenai wewaran adalah naskah Raspatikalpa.Naskah ini merupakan naskah jamak dengan jumlah 18 naskah dengan 1 naskah berjudul berbeda yaitu Basundarikalpa.Naskah ini berisikan tentang wewaran dalam siklus tujuh hari dalam satu pekan atau lebih dikenal

atas 30 minggu atau 210 hari.Wuku terbagi dalam 30 wuku yaitu (1) Sinta; (2) Landep; (3) Wukir; (4) Kurantil; (5) Tolu; (6) Gumbreng; (7) Warigalit; (8) Warigagung; (9) Julungwangi; (10) Sungsang; (11) Galungan; (12) Kuningan; (13) Langkir; (14) Mondosiya; (15) Julungpujut; (16) Pahang; (17) Kuruwelut; (18) Marakeh; (19) Tambir; (20) Madangkungan; (21) Maktal; (22) Wuye; (23) Manail; (24) Prangbakat; (25) Bala; (26) Wugu; (27) Wayang; (28) Kulawu; (29) Dhukut; dan (30) Watugunung (Hadikoesoema, 1985: 19-20).

${ }^{3}$ Pranata mangsa merupakan penanggalan yang dihitung berdasarkan peredaran matahari. Dalam 1 siklus berusia 365 hari.Penanggalan ini digunakan dalam bidang pertanian.Satu tahun terbagi kedalam empat musim utama yaitu ketiga / kemarau (88 hari), labuh (musim pancaroba menjelang hujan, 95 hari), rendheng / penghujan (95 hari), dan marěng (pacararoba akhir musim hujan, 86 hari). Dalam pembagian yang lebih rinci satu tahun dibagi kedalam 12 musim dalam rentang waktu yang bervariasi yaitu kasa/kartika 41 hari, karo/pusa 23 hari, katelu/manggasri 24 hari, kapat/sitra 25 hari, kalima/manggakala 27 hari, kanem/naya 43 hari, kapitw/palguna 43 hari, kawolu/wisaka 26-29 hari, kasanga/jita 25 hari, kasepuluh/srawana 24 hari, desta/padrawana 23 hari, sada/asuji 41 hari. Pranata mangsa digunakan di wilayah Gunung Merapi, Gunung Merbabu, sampai Gunung Lawu jauh sebelum kedatangan pengaruh India.Prinsip-prinsip pranata mangsa berbasis pada peredaran matahari dan rasi bintang Waluku (Orion).Pengetahuan ini diperkirakan telah diwariskan secara turun-menurun sejak periode Kerajaan Medang (lihat Hien, 1922: 310-355; Daldjoeni, 1984: 15-18). dengan saptawara. Dari ke-18 naskah ini hanya beberapa naskah yang kondisinya dikatakan baik, sebagian besar naskah dalam kondisi rusak dan cacat karena dimakan usia.

Naskah Raspatikalpa ditulis di atas lontar dengan menggunakan aksara $b u d a^{4}$ atau gunung dalam penulisannya, bahasanya menggunakan ragam bahasa tengahan ${ }^{5}$. Naskah tertua yang ditemukan ditulis pada tahun 1570 Tahun Jawa MM $^{6}$. Aksara yang berbeda, ragam bahasa yang sudah tidak dikenali lagi, membuat isi naskah Raspatikalpa tidak dapat dijangkau oleh masyarakat luas. Apalagi mengingat usia naskah yang sudah begitu tua dan kondisi naskah yang sudah hampir rusak, perlu dilakukan penyelamatan agar isi naskah dapat dinikmati oleh khalayak banyak. Untuk itu penelitian terhadap naskah ini penting untuk dilakukan. Pengkajian naskah dilakukan dengan menggunakan ilmu bantu filologi mutlak dilakukan. Hal ini untuk mendapatkan naskah yang bersih dari kesalahan, sehingga bisa dibaca oleh khalayak umum.

\section{B. METODE PENELITIAN}

Penelitian ini merupakan jenis penelitian pustaka (library research), yang

\footnotetext{
${ }^{4}$ Aksara buda atau dikenal dengan aksara gunung, menurut Ranggawarsito merupakan aksara yang digunakan oleh para kawi yang tinggal digunung.Aksara ini memiliki karakteristik yang menarik, dan berbeda dengan aksara Jawa (hanacaraka).

${ }^{5}$ Ragam bahasa Jawa dibedakan menjadi 3 yaitu bahasa Jawa Kuna, Jawa Tengahan dan Jawa Baru. Ragam Jawa Kuna digunakan untuk penulisan kakawin diperkirakan digunakan pada abad 9-14 M, bahasa Jawa Tengahan digunakan dalam penulisan kidung diperkirakan digunakan pada abad 14-16, dan bahasa Jawa Baru digunakan dalam penulisan sastra keraton pada abad 16-sekarang.

${ }^{6}$ Tahun Jawa Merapi-Merbabu, hingga saat ini belum ditentukan dengan pasti apakah sistem kalender yang digunakan dalam Naskah Merapi-Merbabu apakah kalender Çaka atau kalender Sultan Agung.
} 
bertujuan untuk mengumpulkan data-data informasi dengan bantuan, buku, majalah, naskah, cetakan, kisah sejarah atau dokumen lain yang relevan (Kartono, 1983:20). Sifat dari penelitian ini adalah penelitian kualitatif deskriftif analitif yang berarti menganalisis dengan menggambarkan, melukiskan, melaporkan, menulis objek penelitian berdasarkan data yang ditemukan.Teknik yang digunakan dalam penelitian ini adalah teknik perbandingan naskah untuk mendapatkan naskah yang mendekati asli yang kemudian diikuti dengan teknik interpretasi untuk memaknai teks secara utuh.

Pengumpulan data dilakukan dalam tiga tahapan berdasarkan yang pertama adalah membaca sumber informasi berupa katalog, yang memuat naskah MerapiMerbabu; kedua dengan membuat catatan mengenai judul naskah dan keterangan lain yang kemudian dilakukan pelacakan ditempat penyimpanan naskah; yang terakhir adalah menggunakan teknik fotocopi atau fotografi dan trasnliterasi.

Analisis filologi dilakukan dalam tiga tahapan deskripsif, komparatif dan interpretasi.Deskriptif dilakukan dengan menggambarkan naskah secara lengkap dan utuh, pendeskripsian biasanya terdapat dalam identifikasi naskah.Komparatif dilakukan dengan membandingkan naskah untuk menentukan silsilah naskah dan menentukan naskah dasar.Interpretasi teks dilakukan untuk menginterpretasi varianvarian dalam kritik teks dan juga dalam terjemahan dan pemaknaan isi naskah.

Metode penelitian filologi berdasarkan jumlah naskahnya dibedakan menjadi dua yaitu naskah tunggal dan naskah jamak. Edisi naskah pada naskah tunggal dilakukan dengan cara diplomatik atau standar. Edisi naskah jamak dilakukan dengan cara gabungan atau landasan. Edisi diplomatik dilakukan apabila naskah merupakan naskah sakral, karena dalam edisi diplomatik disajikan sama persis seperti dalam sumber naskah. Edisi standar dilakukan dengan memperbaiki dan meluruskan teks dari berbagai penyimpangan yang terjadi akibat proses salah salin. Edisi gabungan dilakukan jika kualitas naskah hampir sama dan tidak ada yang menonjol. Edisi landasan dilakukan apabila salah satu naskah lebih menonjol kualitasnya (Baried dkk., 1994:67-68).

Untuk dapat memahami edisi teks yang ditampilkan, perlu dilakukan penerjemahan, karena tidak semua pembaca mengerti bahasa Jawa ragam tengahan.Teknik yang digunakan dalam menerjemahkan Raspatikalpa adalah dengan menggabungkan terjemahan bebas dan terjemahan parsial.Terjemahan bebas dilakukan dengan parsial.

\section{HASIL DAN BAHASAN \\ 1. A nalisis Filologi Raspatikalpa}

Naskah Raspatikalpa berjumlah 17 naskah dengan 1 naskah berjudul berbeda yaitu Basundarikalpa yang kesemuanya merupakan koleksi dari PNRI. Dalam katalog naskah Merapi-Merbabu naskah dengan judul Raspatikalpa memiliki nomer koleksi; 41 (R) $)^{7}, 81$ (B), 124 (C), 125 (J), 131 (A), 167 (H), 197 (I), 205 (Q), 215.1 (G), $215.3(\mathrm{M}), 223(\mathrm{P}), 261(\mathrm{O}), 264(\mathrm{~N})$, 274 (L), 284 (F), 303 (E) dan 390 (D). Naskah dengan judul Basundarikalpa memiliki nomor koleksi 130 (K). Naskah $\mathrm{K}$ merupakan naskah setopik dengan Raspatikalpa meskipun memiliki judul yang berbeda. Kedelapan belas naskah ini tidak semuanya memiliki kelengkapan isi cerita maupun kelengkapan episode, hanya 12 naskah yang memiliki kelengkapan episode, dan hanya 8 naskah yang dalam kondisi utuh atau baik. Naskah dengan nomor koleksi 41 merupakan naskah yang belum jadi karena masih berupa material mentah. Berdasarkan kolofonnya naskah tertua berasal dari tahun 1570 tahun Jawa MM, naskah ini memiliki nomor koleksi

\footnotetext{
${ }^{7}$ Kode naskah untuk mempermudah dalam melakukan perbandingan secara keseluruhan. Pengkodean ini dilakukan dengan melakukan perbandingan awal, dengan melihat usia, bahasa dan kelengkapan episode.
} 
131. Penulisan naskah tersebar dari lereng Gunung Karurungan, Gunung Merapi, Gunung Merbabu, Gunung Darmadan Gunung Pamrihan.

Untuk menentukan pertalian antarnaskah dilakukan perbandingan pada ke-18 naskah di atas yang meliputi perbandingan bahasa, episode, ilustrasi, dan kelengkapan isi setiap episodenya. Berikut adalah bagan pertalian antarnaskah:
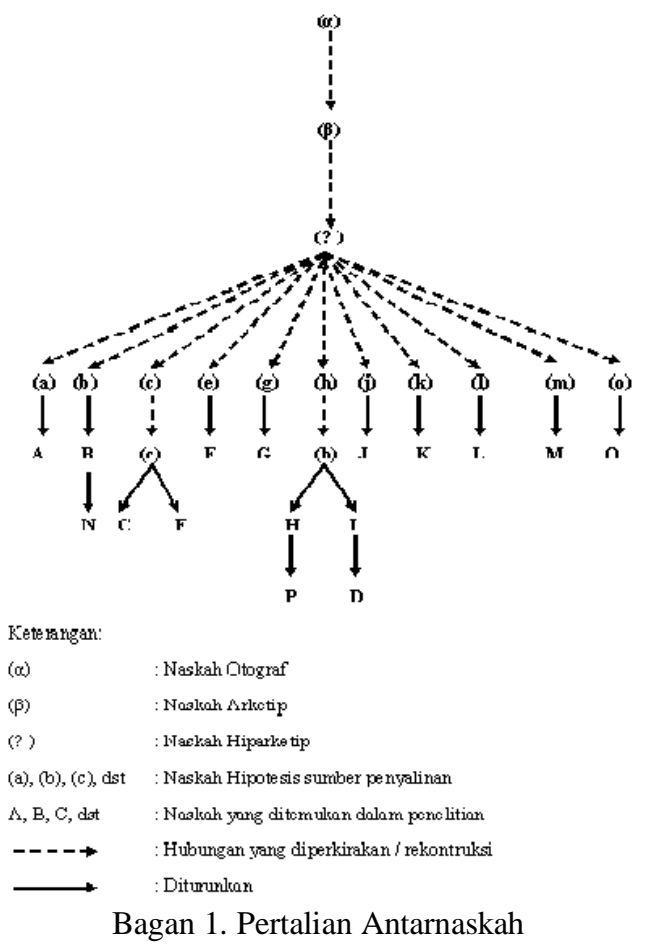

Sumber: Tesis Horoskop Jawa pada Abad 16 dalam Naskah Raspatikalpa oleh Lilis Restinaningsih.

Dari pertalian naskah di atas diketahui bahwa kedelapan belas naskah tersebut merupakan naskah seversi namun memiliki induk naskah yang berbeda. Untuk menentukan naskah sumber edisi dilakukan perbandingan kembali terhadap tiga naskah yang memiliki kualitas terbaik yaitu naskah A, B dan C. Perbandingan yang dilakukan berupa perbandingan kasus salah tulis.

Kasus salah tulis dalam filologi terbagi menjadi 4 kasus utama yaitu Subtitusi (kasus salah tulis yang disebabkan oleh kemiripan ejaan atau pun huruf); Omisi (kasus salah tulis yang terjadi karena hilangnya atau tidak tercantumnya huruf, suku kata, atau pun kata); Adisi (kasus salah tulis yang disebabkan karena kelebihan huruf, suku kata ata pun kata); dan Transposisi (kasus salah tulis yang terjadi karena pertukaran posisi urutan huruf pada tataran kata, kata dalam tataran klausa atau kalimat, kalimat dalam tataran paragraf. (Darsa, 1998: 97126; Raynold \& Wilson 158-159; Partini, 1986: 164).

Kasus subtitusi terjadi pada naskah A, B, dan C. Pada naskah A dan B kasus subtitusi didominasi oleh kesalahan tulis akibat kemiripan huruf terutama pada huruf $\mathbf{T a} \leftrightarrow \mathbf{K a}, \mathbf{W a}^{2} \leftrightarrow \mathbf{G a}^{\top}$ Da

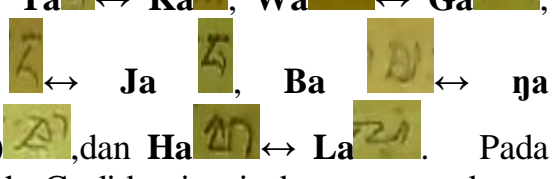
naskah $\mathrm{C}$ didominasi dengan pertukaran

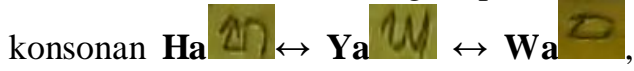
pertukaran ini karena ketiga huruf tersebut masih dianggap dalam ejaan yang sama. Kasus subtitusi paling banyak terjadi pada naskah C yaitu sebanyak 97 kasus, kemudian diikuti naskah B 33 kasus dan naskah A 26 kasus. Pada naskah C penyalin banyak melakukan pergantian konsonan $\mathbf{w} \leftrightarrow \mathbf{y}$, yaitu akhiran -nya ditulis dengan -nwa. Naskah B dan naskah A mengalami kasus pergantian huruf yang lebih variatif. Penyalin naskah A, B, C ada kecenderungan melakukanpertukaran $\mathbf{y} \leftrightarrow \mathbf{w}$ untuk kata swahah ditulis dengan syahah. Dalam naskah A penyalin tidak konsisten dalam penulisan taniha ataupun wehanya, yang terkadang ditulis dengan taniya atau weyanya $(\mathbf{y} \leftrightarrow \mathbf{h})$.

Kasus pertukaran $\mathbf{y} \leftrightarrow \mathbf{w} \leftrightarrow \mathbf{h}$ adalah hal lumrah digunakan dalam teks Merapi-Merbabu hal ini disebabkan penggunaan ketiganya dianggap benar pada masa itu.

Kasus Omisi terbagi menjadi 3 yaitu haplografi, lakuna, dan saut de méme au méme.Haplografi keterlampauan dalam 
tataran huruf atau silabel. Lakuna keterlampauan dalam tataran kata.Saut de méme au méme keterlampauan dalam tataran, frasa, kalimat, atau bagian episode akibat kata yang hampir sama atau mirip (Darsa, 1998:99-100; Djamaris, 2002:35). Omisi terjadi pada naskah $\mathrm{A}, \mathrm{B}$, dan $\mathrm{C}$. Kasus omisi didominasi oleh Haplografi yang terjadi pada naskah $\mathrm{C}$ yaitu sebanyak 98 kasus naskah B 87 kasus dan naskah A 58 kasus, haplografi terjadi karena pelesapkan konsonan $\mathbf{n}$, m, dan ng serta vokal ̌̌ dan a. Kasus lakuna menempati urutan kedua banyak terjadi pada naskah B dan C yaitu sebanyak 35 dan 36 kasus, sedangkan naskah A hanya 17 kasus. Untuk kasus saut de méme au méme banyak terjadi pada naskah B terutama pada akhir episode, hal ini disebabkan untuk meringkas isi teks sudah tidak ada ruang untuk menulis.Pada naskah $\mathrm{C}$ saut de méme au méme biasanya terjadi di tengah episode, biasanya terjadi karena kelalaian pengarang. Pada naskah A hanya terjadi satu kasus saut de méme au méme, ini juga diakibatkan karena kelalaian penyalin karena pengaruh kata sebelumnya sehingga penyalin melewatkan kata yang sama pada kalimat berikutnya.

Kasus Adisi terbagi menjadi 2 yaitu diftografi dan interpolasi. Pada penelitian hanya ditemukan kasus diftografi (pengulangan aksara yang berbeda ataupun penambahan silabel dalam tataran kata). Diftografi terjadi karena adanya penggunaan fonem pelancar, hal ini disebabkan penyalin, menyalin teks berdasarkan cara pelafalan teks, misalnya kata rinaji (ringaji) dibaca rin aji; ban̉bań yawak dibaca bańban்g awak; aksara na inilah yang disebut sebagai fonem pelancar. Diftografi banyak terjadi pada naskah A yaitu 139 kasus, naskah B 65 kasus, dan naskah $\mathrm{C} 70$ kasus.

Transposisi terbagi menjadi 4 kasus yaitu pertukaran aksara, sinonimi, metatesis, dan akronim (Darsa, 1998:123126). Secara keseluruhan transposisi yang terjadi pada naskah A sebanyak 31 kasus yang didominasi kasus pertukaran aksara
15 kasus, sinonimi 7 kasus, metatesis 2 kasus dan akronim 7 kasus. Pada naskah B sebanyak 61 kasus yang didominasi oleh sinonimi sebanyak 27 kasus pertukaran aksara 12 kasus, metatesis 3 kasus dan akronim 19 kasus. Pada naskah C sebanyak 58 kasus didominasi oleh sinonimi sebanyak 22 kasus, pertukaran aksara 12 kasus, metatesis 15 kasus, dan akronim 8 kasus . Pertukaran aksara terjadi karena ketidakkonsistenan penggunaan $\mathbf{b}$, $\dot{\mathbf{t}}$, s, dan t. Kasus metatesis didominasi pertukaran frasa dalam kalimat.Akronim digunakan untuk menyingkat kata mantra (ma)dan rasinya (ra).

Kasus tak teridentifikasi, pada naskah A ditemukan kasus yang belum dapat diidentifikasikan jenis kasus salah tulisnya, seperti kata kunang yang diedisikan menjadi kata sanak guna memenuhi konteks kalimat, begitu juga dengan kata ing giri yang diedisikan menjadi kata indra, kata gayan diedisikan menjadi haywa dan lain-lain.

Selain kasus di atas dalam ketiga naskah juga ditemukan corruptela yang terjadi akibat kerukan naskah. Naskah yang cacat dan berlubang membuat pembacaan teks sulit dilakukan. Pada naskah A terjadi 2 kasus, naskah B 42 kasus dan naskah C 19 kasus.

Secara keseluruhan kasus yang terjadi sebanyak 970 kasus dengan rincian naskah A 280 kasus, naskah B 320 kasus dan naskah C sebanyak 380 kasus, berikut adalah diagram rincian kasus pada naskah A, B dan C: 


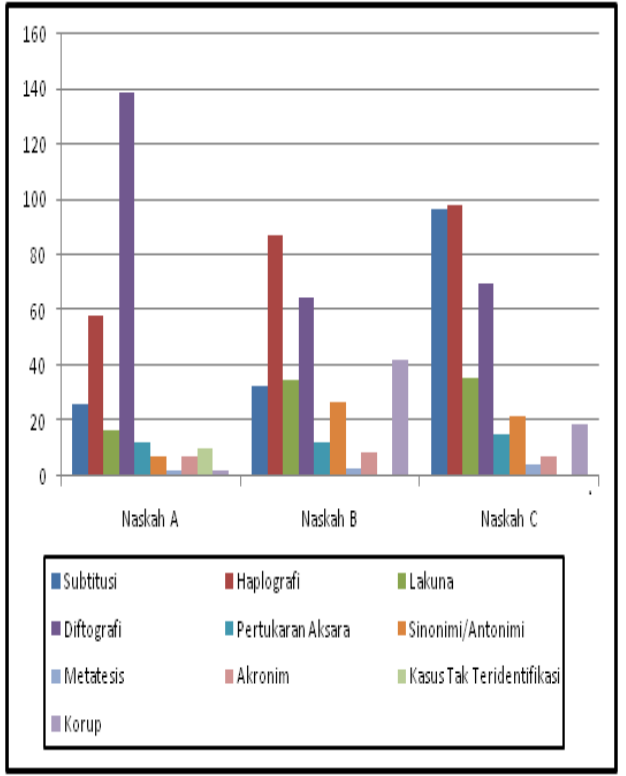

Bagan 2.Diagram Kasus Salah Tulis pada Naskah A, B dan C.

Sumber : Tesis Horoskop Jawa pada Abad 16 dalam Naskah Raspatikalpa Oleh Lilis Restinaningsih.

Berdasarkan kasus salah tulis di atas dapat disimpulkan bahwa naskah yang digunakan sebagai naskah dasar edisi dan terjemahan adalah naskah $\mathbf{A}$ (naskah dengan nomor koleksi 131). Penyajian edisi teks menggunakan metode naskah jamak yaitu landasan dengan menggunakan naskah $\mathrm{B}$ dan $\mathrm{C}$ sebagai naskah saksi. Perbaikan edisi teks dilakukan dengan mengembalikan katakata yang bersumber dari bahasa Jawa Kuna dan Sanskerta ke dalam bentuk aslinya selama masih memungkinkan dengan menghilangkan tanda dirgha (suara panjang), sedangkan kata-kata yang sudah mengalami penyerapan total dalam bahasa Jawa Baru distandarisasikan menurut kamus Winter dan Ronggosito maupun Poerwodarminta.

Raspatikalpa memiliki tujuh episode yang berisikan tentang perwatakan manusia berdasarkan hari lahirnya. Dalam setiap episodenya memiliki kerangka isi yang sama, yaitu
1) Padewaan, awal setiap episode berisi mengenai padewan yang menaungi hari lahir. Padewaan ini berkaitan dengan dewa, yang menaungi, urip ${ }^{8}$, yoni, pancawara, wayang serta unsurunsur alam yang menaungi hari lahir.

2) Gambaran fisik dan gambaran sifat, yang meliputi bentuk muka, warna kulit, postur tubuh, cara bicara dan juga sifat dasar manusia yang melekat pada hari lahir.

3) Pekerjaan, pekerjaan yang disarankan berdasarkan hari lahirnya.

4) Penyakit, penyakit yang mungkin diderita seseorang berdasarkan hari lahirnya.

5) Ruwatan, ruwatan yang harus dilakukan dengan sarana dan mantra tertentu sesuai dengan hari lahir.

6) Letak arah bangunan, arah menentukan usaha dan masalah keuangan.

\section{Hari dalam Tradisi Jawa}

Hari (dina) dalam Bausastra Djawa dideskripsikan sebagai wayah rina; waktu wiwit pletheking srěngenge tekan surup; suwe ning wektu (awan karo bengi 24 jam), "hari merupakan waktu siang; waktu dari terbit matahari sampai waktu malam (magrib); lamanya waktu (siang dan malam 24 jam)" (Poerwadarminta, 1939: 68). Dalam masyarakat Jawa tradisional pergantian hari dalam siklus 1 hari, bukan berada pada pukul 24.00, tetapi berada pada pukul 18.00 atau saat waktu matahari terbenam.

Siklus hari dalam budaya Jawa ada 10 jenis, yaitu ekawara (perhitungan hari dengan siklus 1 harian: luang); dwiwara (perhitungan hari dengan siklus 2 harian: menga dan pepet); triwara (perhitungan hari dengan siklus 3 harian: pasah, beteng, dan kajeng); caturwara (perhitungan hari dengan siklus 4 harian: sri, laba, jaya, dan

${ }^{8}$ Urip atau sekarang lebih dikenal denganneptu adalah angka tertentu yang disematkan pada tiap-tiap hari, pasaran, bulan, dan wuku.Nilai urip/neptu inilah yang digunakan sebagai dasar perhitungan hari baik dan hari buruk. 
manala); pancawara (perhitungan hari dengan siklus 5 harian: kliwon, legi/manis, pahing, pon, dan wage); sadwara (perhitungan hari dengan siklus 6 harian: tunglě, aryang, warukung, paningron, uwas, dan mawulu); saptawara (perhitungan hari dengan siklus 7 harian: radite, soma, anggara, buda, raspati, sukra, dan saniscara); hastawara (perhitungan hari dengan siklus 8 harian: sri, indra, guru, uma, yama, rudra, brahma dan kala); nawawara (perhitungan hari dengan siklus 9 harian: urungan, tulus, dadi, dangu, jangur, gigis, nohan, ogan, dan erangan); dan dasawara (perhitungan hari dengan siklus 10 harian: pandita, pati, suka, duka, sri, manut, manusa, eraja, dewa, dan raksasa).

Siklus hari yang masih digunakan hingga saat ini adalah siklus 5 harian dan siklus 7 harian. Kedua siklus hari tersebut digunakan untuk menghitung hari baik untuk keperluan daur hidup, seperti perjodohan, menentukan tempat usaha yang baik, menentukan waktu bercocok tanam, membangun ataupun pindah rumah, menghitung pekerjaan yang cocok, dan menghitung nama yang baik untuk anak yang baru lahir. Keberadaan hari bagi masyarakat Jawa, memiliki arti penting tersendiri. Hari dipandang sebagai manifestasi dari jagad besar (alam semesta) dan jagad kecil (diri manusia).

Penciptaan alam semesta dalam kepercayaan orang Jawa terjadi dalam tujuh tahapan. Pertama adalah radite, ketika Tuhan memiliki kehendak ingin menciptakan dunia. Kehendak Tuhan ini lalu disimbolkan dengan matahari yang bersinar sebagai sumber kehidupan. Kedua adalah soma, ketika Tuhan menurunkan kekuatan-Nya untuk menciptakan dunia. Kekuatan Tuhan itu lalu disimbolkan dengan bulan yang bercahaya tanpa menyilaukan. Ketiga adalah anggara, ketika kekuatan Tuhan tadi mulai menyebarkan percik-percik sinar Tuhan. Percik sinar Tuhan itu lalu disimbolkan dengan api yang berpijar. Keempat adalah buda, ketika Tuhan menciptakan dimensi ruang untuk wadah alam semesta. Dimensi ruang itu lalu disimbolkan dengan bumi menjadi tempat makhluk hidup. Kelima adalah raspati, ketika tuhan menciptakan panas yang menyalakan kehidupan. Panas yang menyala itu lalu disimbolkan dengan angin yang bergerak dan petir yang menyambar. Keenam adalah sukra, ketika tuhan menciptakan air yang dingin. Air yang dingin itu lalu disimbolkan dengan bintang yang mirip titik-titik air yang menyejukkan. Ketujuh adalah saniscara, ketika Tuhan menciptakan unsur materi kasar sebagai dasar pembentuk kehidupan. Materi kasar itu lalu disimbolkan dengan air sebagai sumber kehidupan (Ranoewidjojo, 2009: 3-30).

Perwatakan manusia dipengaruhi oleh padewaan dan unsur-unsur alam yang menaungi. Unsur dewa memengaruhi warna, bunga, arah, syarat ruwatan, mantra, dan pancawara.Unsur dewa pula yang memengaruhi urip, yang dimiliki setiap hari lahir. Dalam mitologi wewaran, urip berkaitan dengan pertarungan dewa dan kala, dimana dewa merupakan manifestasi kebaikan dan kala merupakan manifestasi hal-hal buruk. Dalam peperangan dewa tidak selamanya menang, dewa bisa kalah dan dihidupkan kembali. Karena kekalahan dewa akan melakukan yoga untuk lebih mendekatkan diri pada Hyang Widi. Hari-hari dimana dewa beryoga inilah yang kemudian dianggap sebagai hari baik dan hari-hari dimana dewa kalah dianggap sebagai hari buruk (Namayudha, 1993:39).

Setiap hari lahir memiliki urip atau neptu yaitu nilai angka yang disematkan pada tiap-tiap hari atau pasaran (Ranoewidjojo, 2009: 26).Urip atau neptu inilah yang digunakan untuk menghitung hari baik. Nilai urip atau neptu dipengaruhi oleh padewaan yang menaungi. Padewaanini juga yang memengaruhi arah, warna dan pancawara yang sesuai berdasarkan hari lahir. 
Tabel 1: Hari dan Padewaan

\begin{tabular}{|c|c|c|c|c|c|}
\hline 岢 & 莡 & 音 & 苞 & 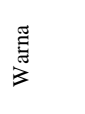 & 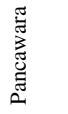 \\
\hline Radite & Iswara & 5 & Timur & Putih & Manis \\
\hline Soma & Giri & 4 & Utara & Hi-tam & Wage \\
\hline Anggara & Rudra & 3 & Barat daya & Jing-ga & \\
\hline Buda & $\begin{array}{c}\text { Mahade } \\
\text { wa }\end{array}$ & 7 & Barat & $\begin{array}{l}\mathrm{Ku}- \\
\text { ning }\end{array}$ & Pon \\
\hline Raspati & $\begin{array}{c}\text { Mahesw } \\
\text { ara }\end{array}$ & 8 & Teng-gara & $\begin{array}{c}\text { Saliwa } \\
\mathrm{h}\end{array}$ & $\begin{array}{l}\text { Kli- } \\
\text { won }\end{array}$ \\
\hline Sukra & Wis-nu & 6 & Timur laut & $\begin{array}{c}\text { Abu- } \\
\text { abu }\end{array}$ & Wage \\
\hline Sanis-cara & Durga & 9 & Sela-tan & Me-rah & $\begin{array}{c}\text { Pa- } \\
\text { hing }\end{array}$ \\
\hline
\end{tabular}

Konsep hari dalam kebudayaan Jawa selalu berkaitan dengan upacara daur hidup manusia. Upacara adalah tanda-tanda kebesaran; peralatan (menurut adat istiadat); rangkaian tindakan atau perbuatan yang terikat pada aturan tertentu menurut adat dan agama; perbuatan atau perayaan yang dilakukan atau diadakan sehubungan dengan peristiwa penting (Hasan, 1995:1108). Daur hidup manusia adalah rangkaian tahapan yang dilalui manusia dari lahir, remaja, dewasa, hingga kembali ke sang pencipta. Upacara daur hidup manusia dapat disimpulkan sebagai rangkaian ritual yang dilalui manusia untuk menandai tingkat kedewasaannya seseorang.

Upacara daur hidup dalam masyakarat Jawa dimulai dari upacara manusia saat didalam kandungan, kemudian saat manusia lahir, masa remaja, perkawinan hingga kematian.Upacara saat dalam kandungan dimulai dari empat bulanan, kemudian dilanjutkan tujuh bulanan atau tingkeban. Upacara kelahiran diawali dengan upacara brokohan, kemudian puput puser, dilanjutkan dengan selapanan. Upacara pada masa remaja yaitu sunatan pada lelaki, dan pangkur gigi pada perempuan. Upacara kematian dimulai dari nelung dina (tiga hari), pitung dina (tujuh hari), patang puluh (empat puluh hari), nyatus (seratus hari), mendhak pisan (satu tahun), mendhak pindo (dua tahun), nyewu dina (seribu hari), hingga nyewindu (8 tahun)

Pelaksanaan daur hidup tidak bisa dilakukan dengan begitu saja. Pelaksaannya harus dilaksanakan pada hari yang dianggap baik. Pemilihan hari pelaksanaan daur hidup harus didasarkan pada weton $^{9}$ yang dimiliki orang yang memiliki daur hidup tersebut. Pada daur hidup masa dalam kandungan, perhitungan hari baik dihitung berdasarkan perkiraan usia kandungan. Pada saat daur hidup kelahiran, puput puser dan selapanan, dilakukan dengan berdasarkan pada hari lahir si bayi. Begitu juga pada daur hidup masa remaja, pelaksanaan sunatan dipilih hari baik berdasarkan weton yang akan disunat. Pada daur hidup pernikahan ${ }^{10}$,

${ }^{9}$ Weton merupakan perhitungan hari berdasarkan gabungan antara pekan lima harian dan minggu tujuh harian, misalnya Selasa Wage. Perhitungan dilakukan dengan cara menjumlahkan neptu (urip) dari hari yang berasal dari pekan ke-5 dan minggu ke-7.

${ }^{10}$ Pada upacara pernikahan dihitung weton dari mempelai lelaki dan perempuan.Perhitungan weton biasanya didasarkan pada hari lahir gabungan antara saptawara dan pancawara (misal Senin Kliwon).Jumlah weton kedua mempelai dihitung, ditambahkan kemudian dibagi oleh bilangan tertentu.Sisa bilangan pembagian ini nanti yang akan menentukan baik tidaknya pernikahan dilaksanakan. Jika perhitungan dibagi 5 maka jika sisa 1 disebut sri, sisa 2 disebut dana, sisa 3 disebut lara, sisa 4 disebut pati dan sisa 5 disebut lungguh. Jika hitungan jatuh pada sri, dana dan lungguh itu dianggap baik, dan jika perhitungan jatuh pada lara atau pati maka artinya tidak baik.Tapi biasanya perhitungan tidak hanya didasarkan dengan satu perhitungan saja, biasanya digunakan lebih dari 3 rumus untuk menghitung perjodohan.Jika hasilnya dominan 
pelaksanaan upacara pernikahan dihitung berdasarkan weton kedua mempelai yang akan melangsungkan pernikahan. Perhitungannya juga tidak hanya didasarkan pada satu rumus saja.tetapi dihitung dengan berbagai rumus untuk menentukan bahwa pernikahan mereka baik atau tidak.

\section{Perwatakan berdasarkan Raspatikalpa} Subbab sebelumnya telah menyinggung bahwa Raspatikalpa berisikan tentang gambaran watak manusia berdasarkan hari lahir berdasarkan siklus saptawara (radite, soma, anggara, buda, raspati, sukra dan saniscara). Penamaan hari dalam teks Raspatikalpa merupakan bahasa serapan Sanskerta, yang diambil dari nama-nama benda langit. Radite berarti matahari, soma berarti rembulan, anggara berarti Mars, buda berarti Merkurius, raspati berarti Jupiter, sukra berarti Venus, dan saniscara berarti Saturnus.Saat ini saptawara lebih dikenal dengan hari Minggu, Senin, Selasa, Rabu, Kamis, Jumat dan Sabtu. Berikut adalah gambaran watak manusia berdasarkan teks Raspatikalpa:

1) Minggu, berada di bawah naungan Dewa Indra dengan neptu 5, yang lahir di Minggu merupakan pengejawantahan dari Dewa Iswara. Penggambaran tersebut sesuai dengan yang tertuang dalam teks yang berbunyi

'...watěk radite. Bhatara Indra majalma, 5. ... Bhatara Iswara kang ngapiturun...' (...golongan hari Minggu, Dewa Indra menjelma 5 kali ... Dewa Iswara yang mengejawantah ...)

Dalam dunia pewayangan, Dewa Indra diartikan sebagai keindahan seni dan kebudayaan. Dewa Indra bertugas untuk memimpin bidadari

baik, maka perjodohan dianggap baik.Namun jika perhitungan hasilnya tidak baik, biasanya perjodohan dibatalkan atau dicarikan jalan untuk tetap melangsungkan perjodohan dengan cara ruwatan maupun cara yang lain. dan menjaga ketentraman khayangan (Kuning: 2011:69). Untuk itu, orang yang lahir di hari Minggu cocok jika menjadi pemimpin. Orang yang lahir hari Minggu biasanya memiliki wawasan yang luas. Hari Minggu dilambangkan dengan matahari. Matahari merupakan penerang jagat raya. Begitu juga orang yang lahir di hari Minggu, biasanya memiliki perilaku terang hatinya, mudah merelakan segala sesuatu kepada sanak saudara, dan rela memberi tanpa mengharapkan balasan. Dalam teks dikatakan bahwa orang lahir di hari Minggu diibaratkan seperti burung beo. Burung beo bersifat copychat, artinya menirukan apa yang diperintahkan atau diajarkan. Begitu juga dengan orang yang lahir pada hari Minggu memiliki kecenderungan untuk menirukan perilaku orangorang di sekitarnya. Jika salah dalam pergaulan akan berbahaya karena mereka mudah terbawa pada perilaku buruk. Wayangnya mojar, menggambarkan bahwa orang yang lahir di hari Minggu pandai berbicara meskipun ia hanya berbicara seperlunya. Selain itu orang yang lahir di hari Minggu biasanya lemahlembut sifatnya, namun hatinya senantiasa diliputi keraguan sehingga selalu berada di persimpangan jalan. Dalam hal hubungan dengan Tuhan, biasanya orang yang lahir di hari Minggu merupakan orang yang rajin beribadah. Mereka yang lahir di hari Minggu biasanya mencintai istri dan sanak saudaranya. Penggambaran tersebut sesuai dengan yang tertuang dalam teks, yang berbunyi

'...akasa pěs pamběkanya tanaga kol. Tulanya hapras ing pujan.Wicaksana wruh ing keguh. Watěkang gegunani istri sanak...'

(... seperti langit yang lemah-lembut sifatnya. Keraguan meliputi hatinya. Seimbang dalam menjalani upacara pemujaan. Bijaksana dan tahu 
tatakrama ...). Pengaruh Dewa Indra, membawa bakat seni pada orang yang lahir di hari Minggu. Mereka cocok jika bekerja di bidang seni seperti menjadi pelukis atau pun arsitek. Namun mereka juga bisa menjadi petani atau pun guru/pendeta. jika ingin mencari pekerjaan atau memulai usaha carilah tempat ke arah selatan.

2) Senin, berada di bawah naungan Dewa Uma dengan neptu 4 dan dilambangkan dengan rembulan, penggambaran ini terdapat pada awal episode kedua yang berbunyi:

'... watěk soma. Bhatari uma dumadi janma 4 wewehan bhatara guru.bhatara yoninya. Mayanya wulan...'

(...golongan hari Senin.Dewi Uma menjelma 4 kali atas perintah Dewa Siwa. Dewa yoninya, mayanya rembulan...)

Rembulan adalah benda langit yang diidentikkan dengan keindahan, ketenangan, kedamaian, kemewahan dan melankoli. Begitu juga orang lahir di hari Senin, biasanya mereka menyukai ketenangan dan kedamaian. Ketenangan dan kedamaian menjadi tujuan pokok dalam hidupnya. Mereka senang membayangkan kemewahan. Bunganya adalah bunga tunjung hitam, berarti memiliki kepribadian yang baik. Tidak terlalu banyak bicara, namun jika bicara tegas. Pembawaannya ceria walaupun sering sedih sendiri tanpa sebab. Sinar tubuhnya berwarna merah, biasanya mudah marah walaupun hanya sebatas kata-kata saja. Orang yang lahir di hari Senin cenderung senang menolong orang lain atau pun keluarga. Biasanya mereka rela mengorbankan apa pun untuk orangorang yang dicintainya, terutama keluarganya. Perkataannya tidak dapat diremehkan, karena mereka selalu bicara berdasarkan fakta. Sering kali mengalami kegelisahan dan kebingungan karena pikirannya yang bercabang-cabang. Mereka adalah orang patuh terhadap peraturan meskipun sering lalai atau ceroboh. Dalam hal keuangan, mereka cenderung boros ketika masih muda. Pekerjaan yang cocok menurut teks adalah menjadi pendeta, berdagang properti, bertani, atau pun menjadi karyawan.

3) Selasa, orang yang lahir di hari Selasa di bawah naungan Dewa Rudra dengan neptu 3. Penggambaran ini terdapat dalam kalimat :

'...watěk anggara bhatara Rudra dumadi janma 3, wewehan Bhatara Brahma...'

(...golongan hari Selasa, Dewa Rudra menjelma 3 kali atas perintah Dewa Brahma...)

Dewa Rudra merupakan bentuk awatara dari Dewa Siwa saat sedang marah dengan memiliki 8 tangan. Dewa Rudra berwatak keras dan mudah marah. Mereka yang lahir di hari Selasa biasanya memiliki sifat keras kepala dan mudah tersulut emosinya, meskipun demikian orang yang lahir di hari Selasa biasanya disenangi banyak orang karena memiliki kemampuan. Mereka juga senang menolong sahabatnya, mempunyai firasat yang kuat dan pandai mencari peluang. Suaranya keras jika berbicara, selalu konsisten dalam berbagai hal dan mengutamakan keluarga dan saudara. Jika perempuan biasanya memiliki tahi lalat di kemaluannya. Kadang tidak setia dalam hal menjalin hubungan. Dan biasanya jika lelaki kemampuannya (dalam bercinta) dikalahkan oleh istrinya. Sifat buruknya terkadang malas dalam bekerja dan cenderung berani terhadap orang tua. Hal ini sesuai dengan penggambaran dalam teks yang berbunyi:

'... andĕng-andĕngĕn pastane baga yen istri, hakas winarah mĕngĕttuli baredunya tanya těguh sahujanya 
nircaring wuwusnya tanya jĕněk ring sanak istri. Mangka sungkannya tan pisanya krama,pipat mati rabinya, akasing rare. Gegabah, gawehanya angěboho gawehanya, maleca pasanakan...'

(... memiliki tahi lalat di kemaluanya jika perempuan. Suaranya lantang.Konsisten dengan berbagai hal.Teguh memegang ucapannya. Mengutamakan istri dan sanak saudara.Ada kala tidak setia terhadap pernikahannya, (jika lelaki) kemampuanya kalah oleh istrinya. Mencintai anaknya, namun malas bekerja, tidak setia pada saudara...) Pekerjaan yang cocok menurut teks adalah petani, guru, di bidang militer, dan pandai besi.

4) Rabu, orang yang lahir di hari Rabu ada di bawah naungan Dewa Wisnu dengan neptu 7 dan lambangnya awan dan yoninya banci. gambaran ini terdapat pada kalimat:

'...watěk buda. Bhatara Wisnu dumadi jalma 7 wewehan Bhatara Mahadewa.Kĕdi yoninya. Mega mayanya...'

(...golongan hari rabu, Dewa Wisnu menjelma menjadi 7 atas perintah Dewa Mahadewa. Yoninya banci, mega mayanya...)

Mereka yang lahir di hari Rabu cenderung memiliki watak sangat keras jika keras hatinya, dan sangat lembut jika lembut hatinya.Jika lelaki bisa berwatak banci. Lambangnya adalah awan menandakan tenang di permukaan namun sangat susah ditebak keinginannya. Wayangnya goleng menandakan cekatan dalam melaksanakan pekerjaannya. Pembawaannya ceria. Ketika masih muda rajin bekerja untuk mengumpulkan bekal di hari tua. Kata-katanya manis, orang pun segan menolaknya. Sayangnya, orang yang lahir di hari Rabu seringnya tidak memiliki pendirian yang tetap, karena selalu diliputi kebingungan. Ia cenderung mempersenang diri dengan cara berjudi dan minum-minum minuman keras. Juga tidak setia terhadap sanak saudara. Namun ia paham akan kehendak hatinya. Perempuan yang lahir di hari Rabu biasanya banyak bicara (cerewet), merasa tidak puas dengan satu lelaki sehingga senang berselingkuh. Hal ini sesuai dengan penggambaran dalam teks yang berbunyi:

'...Kuding pembekanya. ulad - ulid maredunya, buněk ati. Wikěn palěha totohan maleca pasanakan.Wruh citta wiwiki.Cangkĕm wadon kadawan, lumusir kurang lelanang.Sada muda alon gawehanya harĕp druweni wěbang atuwa sugih.Kumĕd cakap merangan lumuhan...'

(... ceria pembawaannya. Goyah sifatnya, bingung hatinya. Mempersenang hatinya dengan berjudi dan minum minuman keras, tidak setia terhadap saudara namun begitu ia paham kehendak hatinya. Jika perempuan cerewet dan tidak cukup dengan satu lelaki. Ketika muda rajin bekerja mengumpulkan uang untuk hari tua. Manis katakatanya...)

Pekerjaan yang cocok berdasarkan teks adalah bertani, berdagang pakaian, menjadi guru atau pendeta. Ketika sudah menikah penghasilan yang digunakan cukup dari penghasilan suami, jangan dari penghasilan istri.

5) Kamis, orang yang lahir pada hari Kamis di bawah naungan Dewa Guru dengan neptu 8, dengan simbol api. Hal ini tergambar dalam kalimat:

'...watěk raspati Bhatara guru dumadijanma 8 wewehan Bhatara Siwa. Dewi yoninya,mayanya api,kayunya waringin,manuknya měrak...'

(...golongan hari Kamis. Dewa Guru menjelma menjadi 8 atas perintah Dewa Siwa. Dewi yoninya, Mayanya 
api, kayunya beringin, burungnya merak...)

Dewa Guru adalah dewa tertinggi di khayangan. Ia memiliki sangatlah bijaksana, namun juga memiliki sifat sombong yang membuatnya dikutuk oleh kakaknya. Sifat dewa Guru menjadi manifestasi bagi mereka yang lahir di hari Kamis. Mereka memiliki kebijaksanaan dan disenangi banyak orang karena ketampilannya. Mayanya api, menggambarkan bahwa mereka mudah tersulut amarahnya. Burungnya merak menggambarkan biasanya yang lahir di hari Kamis memiliki tampilan yang rupawan dan memikat namun sayang cenderung senang pamer menjadi kaya. Kayu beringin, menggambarkan mereka yang lahir di hari Kamis senantiasa mengayomi dan melindungi orangorang di sekitarnya.Wayangnya dalang, menggambarkan mereka yang lahir di hari Kamis pandai dalam mengatur strategi, namun karena sifat individualisme, membuatnya sering lepas kendali.

Bagi yang lahir di hari Kamis, hendaknya berhati-hati dalam berbicara. Karena apa yang diucapkan sering kali terjadi. Mereka yang lahir di hari Kamis berlandaskan pada ajaran kebenaran dalam berperilaku. Mereka juga mengerti tata krama dan sopan santun. Meskipun begitu mereka adalah orang yang senang bercanda. Sayangnya, mereka yang lahir di hari Kamis senang menerima pujian sehingga mudah ditipu dengan bujuk rayu. Hal ini sesuai dengan gambaran kalimat:

‘...Madina patani kĕdĕp pangucap pragnyan wruh ing kewuh. Hupaksi ring aji darma. Bahud tanapi hajroring krama...'

(...kata yang diucapkan pasti terjadi.Mengerti tata krama.Tingkahnya berlandaskan ajaran kebenaran. Tingkah lakunya disertai gurauan...)
Pekerjaan yang tepat menurut teks adalah sebagai petani, guru atau pendeta dan pujangga.

6) Jumat, mereka yang lahir di hari Jumat mendapat naungan dari Dewi Sri dengan neptu 6 dan berlambang air.

'...watěk sukra Bhatari Sri dumadi janma 6, wewehan Bhatara Wisnu. Manusa yoninya. Mayanya banyu...' (...golongan hari Jumat, Dewi Sri menjelma 6 kali atas perintah Dewa Wisnu. Manusia yoninya. Mayanya air...)

Dewi Sri yang memiliki sifat baik hati, lemah lembut, halus tutur katanya, luhur budi bahasanya, memikat dan menyenangkan semua orang. Mereka yang lahir di hari Jumat memiliki sifat yang tidak jauh berbeda dengan Dewi Sri, disenangi banyak orang dan baik budinya. Burungnya burung perkutut bermakna mereka yang lahir di hari Jumat sering kali disayang oleh orang-orang besar selain itu tutur katanya menarik perhatian orang lain. Mayanya air bermakna pemikirannya susah dihentikan, memiliki banyak ide, karena terus mengalir seperti air membuat dirinya labil. Jika mereka yang lahir di hari Jumat mengikuti ajaran kebenaran mereka akan menjadi sosok yang berguna, pintar dan bijaksana. Mereka yang lahir di hari Jumat senang berprihatin. Biasanya yang lahir di hari Jumat cenderung pendiam. Dia diibaratkan seperti gamelan ngidung, memberi ketenangan kepada orang lain, menentramkan. Bagi yang lahir di hari Jumat, jika mengikuti ajaran kebenaran ia akan menjadi orang yang pintar dan bijaksana. Di saat hari tua akan mendapatkan kasih sayang dari anak-anaknya. Pekerjaan yang cocok berdasarkan teks adalah petani, pedagang, pelayar, atau menjadi guru. 
7) Mereka yang lahir di hari Sabtu berada di bawah naungan Dewi Durga dengan neptu 9.

'...watěk saniscara Bhatara Yama dumadi janma 9 wewehan Bhatari Durga. Rasaksi yoninya.Mayanya angin.Kayunya kěrěh. Manuknya dok...'

(...golongan hari Sabtu Dewa Yama menjelma menjadi manusia 9 kali atas perintah Dewi Durga.Rasaksi yoninya.Mayanya angin. Kayunya kěrěh. Burungnya burung hantu...)

Ia memiliki dualisme sifat, yaitu baik dan buruk. Dimana sifat buruknya muncul terlebih dahulu setelah menjalani ruwatan barulah Durga kembali ke wujud aslinya sebagai Uma. Mereka yang lahir di hari Sabtu memiliki sifat egois dan individualis yang tinggi. Wayang dilěm, bermakna bahwa jika seorang yang lahir hari Sabtu marah, maka pelampiasan marahnya tidak melihat situasi dan kondisi. Burungnya burung hantu, biasanya mereka yang lahir di hari Sabtu senang menyendiri dan memiliki firasat yang tajam. Kebimbangan sering meliputi hatinya, pikirannya sering tak menentu karena sering bertentangan dengan hatinya. Biasa mereka teguh dalam memegang kata-katanya.Sering kali kata yang dilontarkan tajam, sehingga orang yang mendengar merasa segan. Mereka yang lahir di hari Sabtu menyayangi keluarganya, sahabatnya, dan anak-anaknya. Sayangnya mereka yang lahir di hari Sabtu banyak keinginannya dan boros dalam mengelola keuangan.

‘...Bawuh amběknya, wracita wiwiti. Humikan bara sapata. Wisaya sayangsara sěngěn tuli maredunya tani těguh sahujarnya.Terajalan hasyětan hajroning karmanya kawalonbakti.akasing prih, akasing rare...'

(... pikiranya tidak menentu. Teguh kata-katanya.Kata yang keluar dari mulutnya tajam. Penuh kasih sayang dan mencintai keluarganya...)

Pekerjaan yang cocok menurut teks adalah pedagang, petani, guru atau pendeta, dan juga penulis.

\section{Aspek Pragmatis Raspatikalpa}

Raspatikalpa pada masanya memiliki kedudukan yang penting. Hal ini dilihat sering naskah ini disalin. Rasa ingin memiliki dan nilai yang terkandung naskah Raspatikalpa membuat masyarakat pada masanya, mendudukan naskah ini dalam kedudukan yang tinggi. Raspatikalpa dianggap sebagai bagian dari tradisi dan religi oleh masyarakat pada masa itu. Jika ditinjau dari aspek pragmatiknya secara garis besar naskah Raspatikalpa memiliki fungsi:

1) Raspatikalpa sebagai bagian dari falsafah hidup, Raspatikalpa mengandung sejumlah nilai, norma, aturan yang dapat dijadikan sebagai falsafah hidup. Rasapatikalpa dijadikan sebagai alat bantu dalam kehidupan untuk menentukan arah hidup lebih baik.

2) Raspatikalpa bagian dari religiusitas, Sebagai penganut agama pra-Islam, masyarakat Merapi-Merbabu menganggap dengan memiliki atau menyalin naskah merupakan bagian dari religiusitas. Pada masyarakat masa itu menyalin atau menulis naskah sebagai bagian untuk mendapatkan berkah dari yang maha kuasa.

3) Raspatikalpa bagian dari proses inisiasi dalam fase kehidupan manusia, Raspatikalpa berisikan mengenai tata upacara ruwat yang menjadi bagian dari proses inisiasi dalam fase kehidupan manusia. Begitu juga dengan nilai urip atau neptu digunakan untuk melakukan perhitungan dalam proses-proses daur hidup hingga manusia kembali ke sang pencipta

4) Raspatikalpa sebagai jimat Masyarakat Merapi-Merbabu saat 
itu menganggap naskah, salah satunya Raspatikalpa sebagai jimat penolak bala yang harus dimiliki.

\section{PEN UTUP}

Raspatikalpa dengan nomor koleksi 131, merupakan naskah yang paling unggul, untuk itu naskah ini dipilih sebagai naskah dasar. Dalam penerbitan edisi teks digunakan metode edisi landasan, dengan memerhatikan naskah 81 dan 124 sebagai naskah saksi. Naskah Raspatikalpa berisi tentang perwatakan manusia yang didasarkan pada hari lahir dalam siklus saptawara. Padewaan dan unsur alam yang menaungi setiap hari lahir memengaruhi karakteristik dan watak seseorang.Angka / neptu bisa digunakan untuk menghitung hari baik dan buruk jika ditambahkan dengan perhitungan neptu dari pancawara atau pun siklus hari yang yang lain. Secara pragmatis Raspatikalpa berfungsi sebagai bagian dari falsafah hidup, religiusitas, proses inisiasi dalam fase kehidupan manusia dan digunakan sebagai jimat.

Fungsi Raspatikalpa pada masa kini, sudah tidak lagi menjadi bagian dari religiusitas. Perkembangan agama Islam yang pesat, menyebabkan nilai-nilai kebudayaan pra-Islam banyak ditinggalkan oleh sebagian besar masyarakat Jawa. Meskipun demikian, penggunaan hari lahir untuk membantu dalam penentuan keputusan dalam daur hidup masih dilakukan oleh sebagian masyarakat jawa. Proses daur hidup seperti inisiasi seorang anak, pernikahan, mendirikan rumah, atau pun pelaksanaan ruwat untuk tolak bala masih menggunakan hari lahir sebagai patokan dalam pelaksanaan acara tersebut. Raspatikalpa yang tergolong dalam kelompok primbon, saat ini banyak dijadikan sebagai sumber kehidupan (mata pencaharian) oleh sebagian kecil masyarakat dengan membuka praktik konsultasi pencarian hari baik untuk acara tertentu. Hal ini dapat kita lihat dari banyaknya iklan yang bertebaran baik di media masa pada media cetak.
Hari dalam kebudayaan masyarakat jawa, tidak hanya berhubungan dengan manusia sebagai jagat kecil, tetapi juga berkaitan dengan alam semesta sebagai jagat besar. Masyarakat yang hidup di sekitar Gunung Merapi dan Merbabu hingga kini masih menggunakan perhitungan hari baik untuk melaksanakan upacara atau ritual persembahan kepada danyang (dewa) yang menguasai Gunung Merapi atau pun Gunung Merbabu sebagai ucapan terima kasih dan rasa syukur kepada alam yang memberikan tanah yang subur, selain itu ritual tolak bala juga dilakukan agar masyarakat setempat terhindar dari bencana alam. Nilai kesakralan pada naskah Raspatikalpa hanya akan terlihat ketika upacara yang berkaitan dengan alam dilakukan, sedangkan pada kehidupan sehari-hari hanya masyarakat yang masih menganut agama pra-Islam yang masih menganut nila-nilainya secara utuh.

Penelitian ini bersifat dinamis. Pemaknaan dan proses pembacaan ulang memungkinkan pemaknaan terhadap teks menjadi berbeda. Pengalaman dan pengetahuan dapat menimbulkan interpretasi yang berbeda. Naskah ini masih memungkinkan untuk dilakukan pembacaan ulang.

\section{DAFTAR SUMBER}

\section{Jurnal, Makalah, Laporan Penelitian,} Skripsi, dan Tesis

Brandes, JLA. 1889.

Een Jayappatra of Acte van eene Rechterlijke Uitspraak van Çaka 849, TBG 32:98-149.

Darsa, Undang A. 1998.

"Sang Hyang Hayu: Kajian Filologis Naskah Bahasa Jawa Kuno di Sunda pada Abad XVI”. Bandung. Tesis Program Pascasarjana UNPAD.

Daldjoeni, N.1984. 'Pranatamangsa, The Javanese Agricultural Calender Its Bioclimatological and Sociocultural Function in Developing Rural Life' The Environmentalist 4: 15-18. 
Restinaningsih. Lilis. 2014.

Horoskop Jawa pada Abad 16 dalam Naskah Raspatikalpa. Tesis. Bandung: Program Magister FIB UNPAD.

\section{Buku}

Alwi, Hasan. dkk. 2008.

Kamus Besar Bahasa Indonesia. Jakarta:Gramedia.

Djamaris, Edwar. 2002.

Metodologi Penelitian Filologi. Jakarta: Manasco.

Hadikoesoema, R.M. Soenandar. 1985. Pawukon Ilmu Perbintangan Jawa dalam Aksara dan Ramalan Nasib dalam Kebudayaan Jawa. Yogyakarta: Proyek Penelitian dan Pengkajian Kebudayan Nusantara (Javanologi) Dirjen Kebudayaan Departemen Pendidikan dan Kebudayaan.

Hien, H. A. Van.1922.

De Javaansche Geestenwereld. Bandung: A.C NIX \& Co.

Lewis, James R. 2003.

The Astrology Book: The Encyclopedia of Heavenly Influence. Detroit: Visible Ink.

Kartono, Kartini. 1983.

Pengantar Metodologi Research Sosial. Bandung: Alumni.

Kuning, Bendung Layung. 2011. Atlas Tokoh-Tokoh Wayang: dari Riwayat sampai Silsilahnya. Yogyakarta: Narasi.

Namayudha, Ida Bagus-Gina, I Wayan. 1993. Wariga. Denpasar: Direktoral Jendral Bimas Hindu dan Budha Tk. I Bali.

Poerwodarminta, W. J.S. 1939.

Baosastra Djawa. Groningen Batavia: J. B Wolter's Uitgevers Maatschappij.

Pradotokusumo, Partini Sarjono. 1983.

Kakawin Gajah Mada: Sebuah Karya Kakawin Abad ke-20 Suntingan Naskah Serta Tokoh dan Hubungan Antarteks. Bandung: Binacipta.

Ranoewidjojo, Romo RDS. 2009.

Primbon Masa Kini: Warisan Nenek Moyang untuk Meraba Masa Depan. Jakarta: Bukuné.

Raynold, L. D. \& N.G. Wilson. 1978.
Scribesand Scholar: A Guide to the Trasnlations of Greek and Latin Literature. Oxford: The Clarendon Press.

Siti Baroroh Baried, dkk. 1994.

Pengantar Teori Filologi. Yogyakarta: BPPF Seksi Filologi Fakultas Sastra Universitas Gadjah Mada.

Tanojo, R. 1962.

Primbon Djawa (Sabda Pandhita Ratu).Solo: TB. Pelajar.

Winter, Sr. C.F dan R.Ng Ranggawarsita. 2007.

Kamus Kawi-Jawa. Yogyakarta: Gadjah Mada University Press.

Zoetmulder, P.J. 1994.

Kalangwan: Sastra Jawa Kuna Selayang Pandang. Jakarta: Djambatan.

Zoetmulder, P.J. \& S. O. Robson. 1994.

Kamus Jawa Kuna Indonesia. Jakarta: PT. Gramedia.

\section{Sumber Internet}

http://dharmavada.wordpress.com/2011/05/25/ pengertian-dan-mitologi-wewaran/. Diakses pada 01/09/2014 pukul 19:50. 